\title{
Bioconversion of Sugarcane Biomass into Ethanol: An Overview about Composition, Pretreatment Methods, Detoxification of Hydrolysates, Enzymatic Saccharification, and Ethanol Fermentation
}

\author{
Larissa Canilha, Anuj Kumar Chandel, Thais Suzane dos Santos Milessi, \\ Felipe Antônio Fernandes Antunes, Wagner Luiz da Costa Freitas, \\ Maria das Graças Almeida Felipe, and Silvio Silvério da Silva \\ Department of Biotechnology, School of Engineering of Lorena, University of São Paulo, 12-602-810 Lorena, SP, Brazil \\ Correspondence should be addressed to Anuj Kumar Chandel, anuj.kumar.chandel@gmail.com \\ and Silvio Silvério da Silva, silvio@debiq.eel.usp.br
}

Received 10 October 2012; Accepted 19 October 2012

Academic Editor: José Manuel Domínguez González

Copyright (C) 2012 Larissa Canilha et al. This is an open access article distributed under the Creative Commons Attribution License, which permits unrestricted use, distribution, and reproduction in any medium, provided the original work is properly cited.

Depleted supplies of fossil fuel, regular price hikes of gasoline, and environmental damage have necessitated the search for economic and eco-benign alternative of gasoline. Ethanol is produced from food/feed-based substrates (grains, sugars, and molasses), and its application as an energy source does not seem fit for long term due to the increasing fuel, food, feed, and other needs. These concerns have enforced to explore the alternative means of cost competitive and sustainable supply of biofuel. Sugarcane residues, sugarcane bagasse (SB), and straw (SS) could be the ideal feedstock for the second-generation (2G) ethanol production. These raw materials are rich in carbohydrates and renewable and do not compete with food/feed demands. However, the efficient bioconversion of SB/SS (efficient pretreatment technology, depolymerization of cellulose, and fermentation of released sugars) remains challenging to commercialize the cellulosic ethanol. Among the technological challenges, robust pretreatment and development of efficient bioconversion process (implicating suitable ethanol producing strains converting pentose and hexose sugars) have a key role to play. This paper aims to review the compositional profile of SB and SS, pretreatment methods of cane biomass, detoxification methods for the purification of hydrolysates, enzymatic hydrolysis, and the fermentation of released sugars for ethanol production.

\section{Introduction}

Brazil is the biggest producer of sugarcane in the world. In the 2012/13 harvest, for example, it was estimated that more than 602 million tons of sugarcane will be processed by the Brazilian sugar-alcohol mills. The sugarcane is basically consisted of stem and straw. The sugarcane straw (or trash) is divided in three principal components, that is, fresh leaves, dry leaves, and tops. The sugarcane stem are milled to obtain the cane juice, which is subsequent used for sugar (sucrose) or alcohol (ethanol) production. The residual fraction from the sugarcane stem milling is named bagasse.
Sugarcane bagasse (SB) and straw (SS) are normally burned in industries to supply all the energy required in the process. If, instead, both were used for ethanol production, much more ethanol would be produced from each hectare of sugarcane processed.

SB and SS are chemically composed of cellulose, hemicellulose and lignin. Cellulose, and hemicellulose fractions are composed of mixture of carbohydrates polymers. A number of different strategies have been envisioned to convert the polysaccharides into fermentable sugars. One of them, the hemicellulose fraction can be hydrolyzed with dilute acids followed by cellulose hydrolysis with enzymes. The cellulosic 


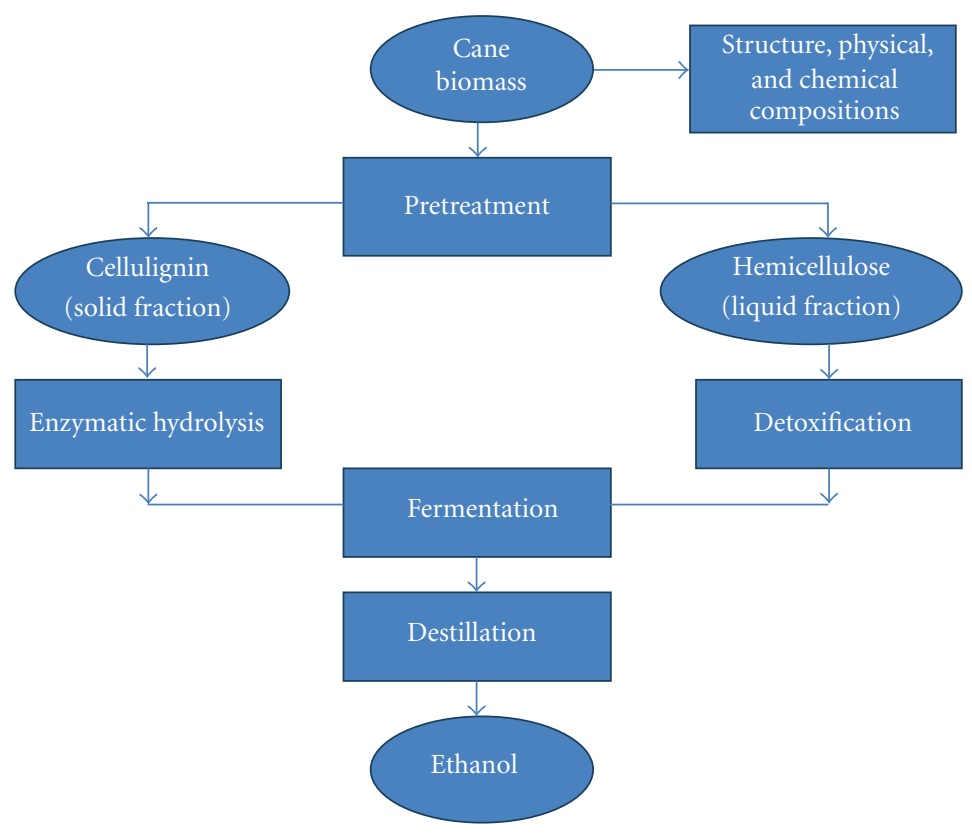

FIGURE 1: Procedural flow diagram for the bioconversion of cane biomass into $2 \mathrm{G}$ ethanol.

fraction is solid rich in glucose, and hemicellulosic fraction is liquid rich in xylose, glucose, and arabinose, where both (solid and liquid) can be fermented to produce ethanol.

In general, the biological process from converting the lignocellulose biomass to fuel ethanol involves: (1) pretreatment either to remove lignin or hemicellulose to liberate cellulose; (2) depolymerization of carbohydrate polymers to produce free sugars by cellulase mediated action; (3) fermentation of hexose and/or pentose sugars to produce ethanol; (4) distillation of ethanol. Ethanol produced from sugarcane residues is one of the most suitable alternatives for partial replacements of fossil fuels because it provides energy that is renewable and less carbon intensive than gasoline. Bioethanol reduces air pollution and also contributes to mitigate climate change by reducing greenhouse gas emissions.

This paper reviews the important information on the structure and chemical composition of sugarcane biomass (SB and SS), pretreatment of biomass, enzymatic hydrolysis of cellulose, conditioning and detoxification of hemicellulosic hydrolysate, bioconversion of sugars into ethanol, and distillation of ethanol (Figure 1).

\section{Sugarcane versus Other Feedstock for the Ethanol Production}

Sugarcane is the main agricultural crop cultivated in Brazil followed by soybean and corn (Table 1). Among the feasible raw materials for ethanol production, sugarcane shows the most promising results because it has a high planted area in the Brazil territory and presents the higher quantity of biomass generated which could be eventually converted into ethanol. The costs of ethanol production are directly related with the costs of feedstock that represents more than onethird of the production costs. Furthermore, the costs of
TABLE 1: Different feedstock cultivated in the Brazilian territory.

\begin{tabular}{lcc}
\hline Biomass & $\begin{array}{c}\text { Planted area } \\
(1000 \text { hectare })\end{array}$ & $\begin{array}{c}\text { Production of biomass } \\
(1000 \mathrm{t})\end{array}$ \\
\hline Wheat & $2,166.2$ & $5,788.6$ \\
Rice & $2,427.1$ & $11,600.3$ \\
Sorghum & 785.1 & $2,204.9$ \\
Cassava & $1,787.5$ & $24,524.3$ \\
Soybean & $25,042.2$ & $66,383.0$ \\
Castor bean & 129.6 & 25.8 \\
Corn & $7,596.3$ & $38,861.8$ \\
Sugarcane & $8,527.8$ & $602,178.8$ \\
Barley & 88.4 & 305.1 \\
\hline
\end{tabular}

Source: Conab [3, 4] and Embrapa [5].

feedstock may vary considerably, depending of its geographic locations, availability, and price $[1,2]$.

According to Conab [3], the Brazilian sugar-alcohol mills will process more than 602 million tons of sugarcane in the 2012/13 harvest, leading the production of roughly 39 million tons of sugar and 24 billion liters of ethanol. Each ton of sugarcane processed by the mills generates approximately $270-280 \mathrm{~kg}$ of bagasse [6] and $140 \mathrm{~kg}$ of straw [7]; thus, it can be inferred that Brazilian mills will produce around 163169 million tons of sugarcane bagasse and 84 million tons of straw only in the 2012/13 harvest.

Nowadays, ethanol producing units employ sugarcane efficiently (first generation). However, it is anticipated that in the coming years, SB along with SS will also be used for $2 \mathrm{G}$ ethanol production. The deployment of the SB and SS for ethanol production is favored in Brazil because the production process can be annexed to the sugar/ethanol units 


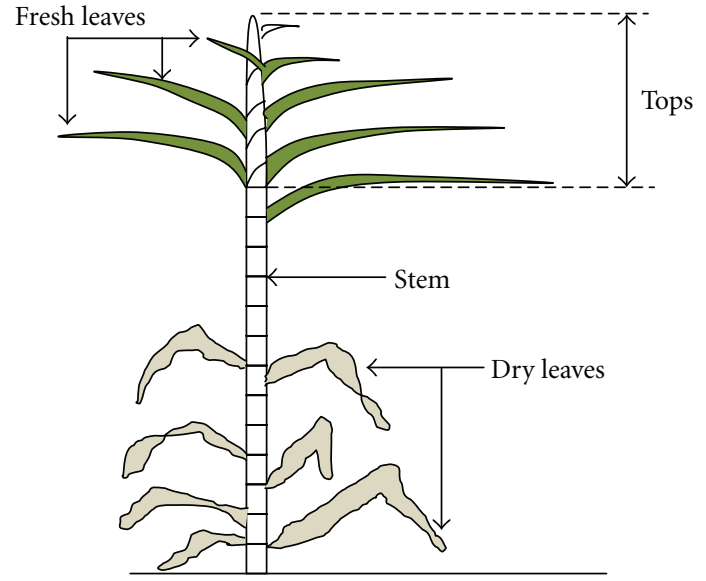

Figure 2: The sugarcane plant morphology. Adapted from [9].

already in place, requiring lower investments, infrastructure, logistics, and energy supply [1]. In such a scenario, more ethanol would be produced from the same amount of sugarcane processed, without increasing the area used to sugarcane cultivation [8]. The yield of ethanol is equivalent to $6,000 \mathrm{~L} /$ hectare planted. It is estimated that ethanol production could reach $10,000 \mathrm{~L} /$ hectare if only half of the SB generated is harnessed for the production of biofuel [1].

\section{Sugarcane Structure}

Sugarcane is any of 6 to 37 species (depending on taxonomic interpretation) of tall perennial grasses of the genus Saccharum (family Poaceae, tribe Andropogoneae). Sugarcane is native of warm temperate climate, common in the tropical regions as Brazil, India, Africa, and Asia pacific. The sugarcane plant morphology can be seen in Figure 2.

Sugarcane is composed by stem and straw (or trash). Sugarcane stem is the material removed before the milling of cane to obtain a juice which is subsequently used for sugar (sucrose) or alcohol (ethanol) production. SB is the residue from stems after extraction of juice. SS (or trash) is composed by fresh leaves, dry leaves, and tops available before harvesting. Fresh leaves are green and yellow in color, tops are the part of cane plant between the top end and the last stalk node, and dry leaves are normally in brownish color [10]. Potential uses of the leaves include: (1) as a fuel for direct combustion; (2) as a raw material for conversion by pyrolysis to char, oil, and/or gas; (3) as a raw material for conversion by gasification and synthesis to methanol. Potential uses for the tops include: (1) as a ruminant feed, either fresh or dried; (2) as a substrate for anaerobic fermentation to methane; (3) after reduction in water content, for the energy uses listed for cane trash $[10,11]$. SB and SS are normally burnt in the open agricultural field after the harvesting of the crop, or in some cases, used as an untapped source of simple sugars that can be utilized for the alcohol production [12].

Characterizing the sugarcane stalk, SS and SB, following observations can be interpreted: the sucrose accumulation is greater at the base of the stem, and the amount of reducing sugars and cellulose contents is superior in the tops; the length of the stem depends on some factors like the variety of the plant and the cultural management given, so that an adult stem may have from less than two meters to over four in size, affecting the length and the number of internodes; the diameter of the stem also varies, oscillating in its middle part from 250 to $350 \mathrm{~m}$; the color depends on the chlorophyll content and that of anthocyanins as well as on aspects of agronomy; there is a large variation in the moisture content of the sugarcane material, varying from $13.5 \%$ (in dry leaves) up to $82.3 \%$ (in the tops); the values of ash, fixed carbon, and volatile matter have little variation among the three components of the straw, with a lower amount of ash for the bagasse; all material present practically the same composition in carbon $(\sim 45 \%)$, hydrogen $(\sim 6 \%)$, nitrogen $(0.5-1 \%)$, oxygen $(\sim 43 \%)$, and sulfur $(\sim 0.1 \%)$; mineral composition for alkalis and phosphorus shows some variation among the three components of the SS, indicating that its content grows from the dry leaves to the tops, and is quite higher than SB $[10,11]$.

\section{Physical and Chemical Compositions of Sugarcane}

Physically, sugarcane is constituted by four major fractions, whose relative magnitude depends on the sugar agroindustrial process: fiber, nonsoluble solids, soluble solids, and water (Figure 3). The fiber is composed of the whole organic solid fraction, originally found in the cane's stem, and characterized by its marked heterogeneity. The nonsoluble solids, or the fraction that cannot be dissolved in water, are constituted mainly by inorganic substances (rocks, soil, and extraneous materials), and it is greatly influenced by the conditions of the agricultural cane processing, types of cutting, and harvesting. Soluble solids fraction that can be dissolved in water are composed primarily of sucrose as well as other chemical components such as waxes, in a smaller proportion [11]. SB or SS which are the focus of $2 \mathrm{G}$ ethanol production are lignocellulosic materials chemically composed by cellulose, hemicelluloses, and lignin.

Cellulose is a linear polymer of glucose units linked by $\beta(1 \rightarrow 4)$-glycosidic bonds, forming cellobiose that is repeated several times in its chain. This cellulosic fraction can be converted into glucose by enzymatic hydrolysis, using cellulases, or by chemical way, using acids like sulfuric acid, that subsequently can be fermented to ethanol $[14,15]$. Hemicellulose is a heteropolysaccharide composed by hexoses (D-glucose, D-galactose, and D-mannose), pentoses (Dxylose, L-arabinose), acetic acid, D-glucuronic acid, and 4O-methyl-D-glucuronic acid units. The hemicelluloses are classified basically according to the sugars that are present in the main chain of polymer: xylan, glucomannan, and galac$\tan [16]$. The hemicellulose differs substantially of cellulose to be amorphous, which make it easier to be hydrolyzed than cellulose [17]. The hemicellulosic fraction can be removed from lignocellulosic materials by some type of pretreatment, like acid or hydrothermal hydrolysis, and liberating sugars, mainly xylose, that subsequently can also be fermented to ethanol $[18,19]$. 


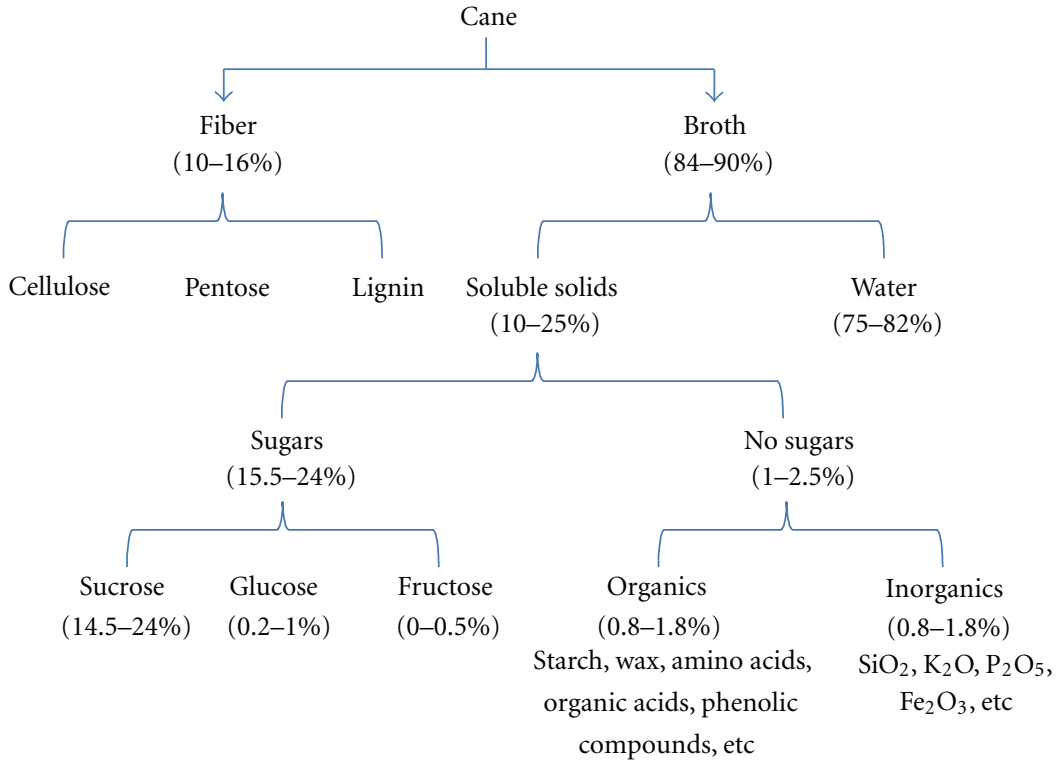

Figure 3: General composition of Sugarcane. Adapted from [13].

TABLE 2: Chemical composition (\% w/w, dry basis) of Brazilian SB reported in the literature.

\begin{tabular}{|c|c|c|c|c|c|c|}
\hline \multirow{2}{*}{ Component (\%) } & \multicolumn{6}{|c|}{ Reference } \\
\hline & Pitarelo [27] $]^{1 *}$ & da Silva et al. $[28]^{2}$ & Canilha et al. [19] ${ }^{3 *}$ & Rocha et al. $[15]^{4 *}$ & Brienzo et al. $[29]^{5}$ & Rabelo et al. $[30]^{6}$ \\
\hline Cellulose & 41.1 & 38.8 & 45.0 & 45.5 & 42.4 & 38.4 \\
\hline Hemicellulose & 22.7 & 26.0 & 25.8 & 27.0 & 25.2 & 23.2 \\
\hline Lignin & 31.4 & $32.4^{\#}$ & 19.1 & 21.1 & 19.6 & 25.0 \\
\hline Ash & 2.4 & 2.8 & 1.0 & 2.2 & 1.6 & 1.5 \\
\hline Extractives & 6.8 & - & 9.1 & 4.6 & - & - \\
\hline Others & - & - & - & - & - & - \\
\hline
\end{tabular}

* Extractives-free basis.

\#Lignin and others.

Extracting solvents: ${ }^{1}$ dichloromethane, ethanol: toluene (1:2), ethanol, and hot water; ${ }^{2}$ none; ${ }^{3}$ water and ethanol; ${ }^{4}$ ethanol; ${ }^{5}$ ethanol; ${ }^{6}$ none.

Lignin is a complex aromatic macromolecule formed by radical polymerization of three phenyl-propane alcohols, namely $p$-coumarilic, coniferilic, and synapilic. In the plant cell wall, lignin and hemicelluloses involve the cellulose elementary fibrils, providing protection against chemical and/or biological degradation [20]. The content of lignin and its distribution are the responsible factors for the recalcitrance of lignocellulosic materials to enzymatic hydrolysis, limiting the accessibility of enzyme, and therefore, the process of delignification can improve the conversion rates of enzymatic hydrolysis [21]. The lignin is primarily used as a fuel, but it can be chemically modified to be used as chelating agent [22], for removal of heavy metals from wastewater [23], or as precursor material for production of add-value products as activated carbon [24], surfactants [25], and adhesives [26].

SB of the Brazilian territory is quantitatively composed by $38.4-45.5 \%$ cellulose, $22.7-27.0 \%$ hemicellulose, and 19.1-32.4\% lignin (Table 2). Nonstructural components of biomass, namely, ashes (1.0-2.8\%) and extractives (4.6$9.1 \%$ ) are the other substances that compose the chemical compositional of bagasse.

The ash content of SB is lower than the other crop residues like rice straw and wheat straw (with approximately 17.5 and $11.0 \%$ of this compound, resp.). SB is also considered a rich solar energy reservoir due to its high yields and annual regeneration capacity (about $80 \mathrm{t} / \mathrm{ha}$ ) in comparison with agricultural residues like wheat, grasses, and trees $(1,2$, and $20 \mathrm{t} / \mathrm{ha}$, resp.) [31]. The bagasse can also be used as a raw material for cultivation of microorganisms and for bioconversion process for the production of industrial enzymes, xylitol, and ethanol production. Due to these advantages the bagasse is considered not only a subproduct of sugar industry, but also a coproduct of high added value [31].

The fact that chemical composition varies for the same type of material did not cause surprise because the major fractions of lignocellulosic materials depend on many factors including plant genetics, growth environment, and 
TABLE 3: Chemical composition (\% w/w, dry basis) of Brazilian SS reported in the literature.

\begin{tabular}{|c|c|c|c|c|c|c|}
\hline \multirow{2}{*}{ Component (\%) } & \multicolumn{6}{|c|}{ Reference } \\
\hline & Moriya $[34]^{1 *}$ & Pitarelo [27] ${ }^{2 *}$ & Saad et al. $[35]^{3 *}$ & da Silva et al. $[28]^{4}$ & Luz et al. $[36]^{5}$ & Costa et al. $[37]^{6}$ \\
\hline Cellulose & 36.1 & 34.4 & 36.1 & 33.6 & 33.3 & 33.5 \\
\hline Hemicellulose & 28.3 & 18.4 & 26.9 & 28.9 & 27.4 & 27.1 \\
\hline Lignin & 26.2 & 40.7 & 26.2 & $31.8^{\#}$ & 26.1 & 25.8 \\
\hline Ash & 2.1 & 11.7 & 2.1 & 5.7 & 2.6 & 2.5 \\
\hline Extractives & 5.3 & 11.5 & 5.3 & - & - & - \\
\hline Others & - & - & - & - & 10.6 & - \\
\hline
\end{tabular}

* Extractives-free basis.

\#Lignin and others.

Extracting solvents: ${ }^{1}$ ethanol; ${ }^{2}$ dichloromethane, ethanol : toluene (1:2), ethanol, and hot water; ${ }^{3}$ water; ${ }^{4}$ none; ${ }^{5}$ none; ${ }^{6}$ none.

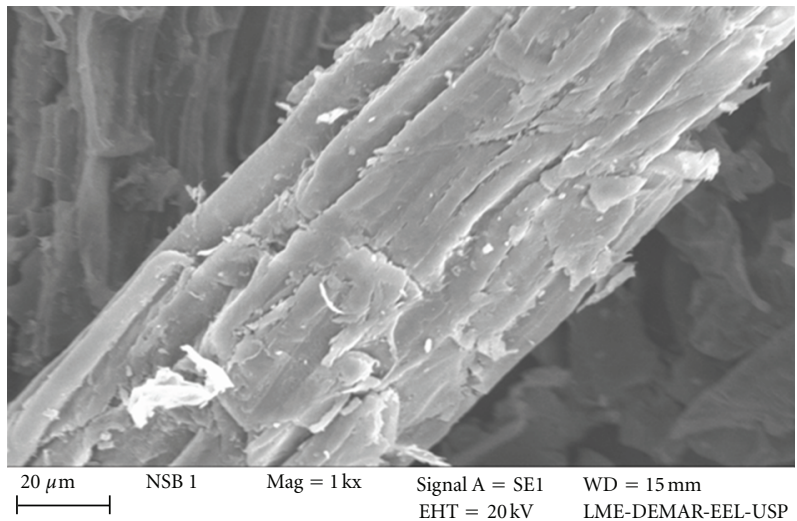

(a)

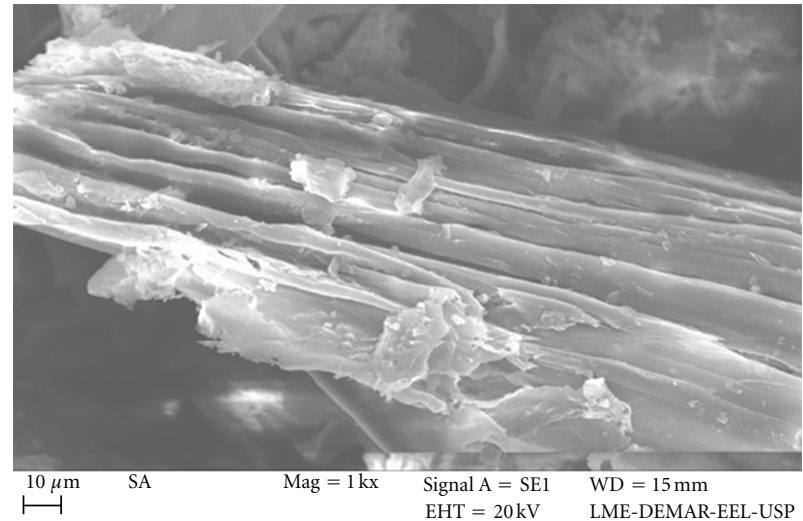

(b)

FIGURE 4: SEM of natural SB (a) and cellulignin obtained after dilute sulfuric acid pretreatment (b) [40].

processing conditions as well as methods employed for the compositional analysis [32]. It is impossible to compare the composition of samples of different origins, performed by different laboratories that do not use the same methods.

The large variation in the values of chemical components also is observed for the SS. Generally it is composed of 33.3$36.1 \%$ cellulose, $18.4-28.9 \%$ hemicellulose, and $25.8-40.7 \%$ lignin (Table 3). Ashes (2.1-11.7\%) and extractives (5.3$11.5 \%)$ are also present in SS. The amount of straw from sugarcane harvesting depends on several factors such as: harvesting system, topping, height, cane variety, age of crop (stage of cut), climate, soil, and others. For example, when mechanically harvested, and depending on the harvesting technology applied, the range of straw that is collected and transported to the mill together with the stems is from $24 \%$ to $95 \%$ of the total trash available [33].

\section{Ethanol Production from Sugarcane Biomass}

Ethanol production from lignocellulosic biomass (second generation) includes pretreatment of biomass, enzymatic hydrolysis of cellulose, fermentation of hexose/pentose sugars, and recovery of ethanol. Intensive efforts have been made in recent years to develop efficient technologies for the pretreatment of SB, developments of enzymes for enhanced cellulose/hemicellulose saccharification, and suitable technologies for the fermentation of both $\mathrm{C}_{6}$ and $\mathrm{C}_{5}$ sugars [1].

5.1. Pretreatment of Sugarcane Biomass. Ideally, the pretreatment of lignocellulosic biomass should (1) increase the accessible surface area and decrystallize cellulose, (2) depolymerize partially cellulose, (3) solubilize hemicellulose and/or lignin, (4) modify the lignin structure, (5) maximize the enzymatic digestibility of the pretreated material, (6) minimize the loss of sugars, and (7) minimize capital and operating costs $[38,39]$.

Figure 4 presents scanning electronic microscopy (SEM) of SB before diluted sulfuric acid pretreatment and of cellulignin obtained after pretreatment. A rupture of cellulosehemicellulose-lignin strong matrix occurred after the pretreatment. In the Figure 4(a), an ordered structure of matrix can be seen, while Figure 4(b) presents a disordered structure of cellulose-lignin complex. It is also possible to find empty spaces between the fibers, as consequence of removal of hemicelluloses and low-crystallinity cellulose flocks [15]. In general, hydrolysate originated after diluted acid pretreatment is rich in the hemicellulose fraction. 
Various pretreatment technologies (alone or in combination) have been proposed in the literature. Broadly, pretreatment technologies can be categorized into 4 types: physical (mechanical); physicochemical; chemical; biological pretreatments. Mechanical pretreatment increases the surface area by reducing the size the SB or SS [41]. A high control of operation conditions is required in the physicochemical methods because these reactions occur at high temperature and pressure [21]. Chemical methods degrade hemicellulose or remove lignin and thus, loosening the structural of ligninholocellulose network. Biological pretreatment methods are used for the delignification of lignocellulosic biomass [42]; however, the longer pretreatment times and loss of a considerable amount of carbohydrates can occur during this pretreatment [43].

Each method has its own specificity in terms of mechanistic application on cell wall components with the applied conditions [42]. Some types of pretreatments (like milling, pyrolysis, steam explosion, ammonia fiber explosion, acid or alkaline cooking, organosolv extraction, and so on) are described as follows.

\subsubsection{Physical Pretreatments}

(1) Milling. Milling is a mechanical pretreatment that breaks down the structure of lignocellulosic materials and decrease the cellulose crystallinity [44]. Ball milling method is most commonly employed, where the contact of the biomass with balls inside a cycle machine reduces the particles size [28]. This method can be considered environment friendly because it does not required chemicals addition [45] and thus inhibitors are not generated [28]. A disadvantage of milling is the high power required by the machines and consequently high energy costs. For sugarcane bagasse pretreatment is necessary for a lot of cycles and many passes through the miller and the cycles usually have a long time of operation [46].

(2) Pyrolysis. The pyrolysis process is carried out at high temperatures (more than $300^{\circ} \mathrm{C}$ ). This process degrades cellulose rapidly into $\mathrm{H}_{2}, \mathrm{CO}$, and residual char [43]. After the separation of char, the recovered solution is primarily composed by glucose, which can be eventually fermented for ethanol production [47]. This process starts with the heating of the biomass. Primary pyrolysis reactions initiate at high temperatures to release volatiles, followed by condensation of hot volatiles and proceeded with autocatalytic secondary pyrolysis reactions [48].

The yield and quality of products after pyrolysis will depend on several parameters which can be categorized as process parameters (temperature, heating rate, residence time, reaction time, reactor type, type and amount of catalyst, type of sweeping gas, and flow rate) [48] and feedstock properties (particle size, porosity, cellulose, hemicellulose, and lignin content [49].

(3) Microwave. Microwave pretreatment is considered as an alternative process for conventional heating. If compared with conventional heating method that uses superficial transfer of heat, microwave pretreatment uses the direct interaction between a heated object and an applied electromagnetic, generating high heating efficiency and easy operation [50]. The main advantage of this process is the short reactions times and homogeneous heating of the reaction mixture [51]. Microwave assisted pretreatment of SB/SS could be a useful process to save time and energy and minimum generation of inhibitors [52].

It can be considered as one of the most promising pretreatment method to change the native structure of cellulose [53], with the occurrence of the lignin and hemicellulose degradation and thus increasing the enzymatic susceptibility [54]. Microwave can be combined with the chemicals further to improve the sugar yield from the substrate [51].

\subsubsection{Physicochemical Pretreatments}

(1) Steam Explosion or Hydrothermal. Steam explosion (or hydrothermal) is one of the most common pretreatment methods. This method can be described as a thermochemical process, where lignocellulosic material is exposed with steam [55]. This pretreatment requires minimum, or in some cases, no chemical addition, then it can be seen as a good technology when it is regarding environment concerns [56]. In this process, a mix of biomass and steam is maintained in high temperature in a reactor, promoting the hemicellulose hydrolysis followed by a quickly decompression ending the reaction [57].

Steam explosion treatment yields high solubility of the hemicellulose (producing mainly oligosaccharides) with low lignin solubility [14]. Usually, temperatures between 160 and $240^{\circ} \mathrm{C}$ and pressure between 0.7 and $4.8 \mathrm{MPa}$ are employed [57]. Steam explosion process followed by enzymatic saccharification is a promising approach to enhance the amount of fermentable sugars.

(2) Ammonia Fiber Explosion (AFEX). AFEX process consists of liquid ammonia and steam explosion. It is a alkaline thermal treatment that exposes the lignocellulosic material to high temperature and pressure followed by fast pressure release. This pretreatment can significantly improve the fermentation rate of various herbaceous crops and grasses [43], and it can be used for the pretreatment of many lignocellulosic materials including alfalfa, wheat straw, wheat chaff, barley straw, corn stover, rice straw, and bagasse [44]. The main advantages of AFEX are the efficient lignin removal and less generation of inhibitors, retaining appreciable amount of carbohydrates in the substrates. Furthermore, it is a simple with short-time process [47]. During the AFEX, structure of the material is changed, resulting in a increase of water holding capacity and of digestibility of substrates (hemicellulose and cellulose) by enzymes, obtaining thus, high sugars recovery $[43,47]$.

The cost of AFEX process could be minimized if the ammonia is recovered from the lignin-rich solution [43, 47]. The parameters that influence the AFEX process are ammonia loading, temperature, high pressure, moisture content of biomass, and residence time $[47,58]$. 
(3) $\mathrm{CO}_{2}$ Explosion. The $\mathrm{CO}_{2}$ explosion occurs similarly to ammonia explosion and is based on the hypothesis that $\mathrm{CO}_{2}$ would form carbonic acid, increasing the hydrolysis rate of the pretreated material [44]. Carbon dioxide molecules are comparable in size to water, penetrating into the bagasse or straw surfaces, improving the hydrolysis of hemicellulose and cellulose fractions. The increase of the pressure during the explosion helps the penetration of $\mathrm{CO}_{2}$ molecules into the crystalline structure of lignocellulosics [43].

$\mathrm{CO}_{2}$ explosion presents conversion yields higher than the steam explosion method, more cost effective than ammonia explosion and does not cause the formation of inhibitors because mild temperature is used during the process, preventing any appreciable decomposition of monosaccharides $[43,59]$. This method is nontoxic, noninflammable, and environmental friendly. However, it is a method with hard operation and process complexities [60].

(4) Hot Water. This method employs hot water under high pressure in the biomass hydrating the cellulose and removes a considerable part of hemicellulose fraction. One of the main advantage of this process is the no use of chemicals and consequently not necessary to use corrosion-resistant materials in the hydrolysis reactor. In addition, reduction the size of the raw material is also not required [61].

Usually, in this process the hot water is maintained in contact of the biomass for about 15 minutes at a temperature of $200-230^{\circ} \mathrm{C}$. During this process, about $40-60 \%$ of the total biomass is dissolved, and all hemicellulose is removed. This process is generally used for pretreatment of corn fibers and herbaceous crops [62].

\subsubsection{Chemical Pretreatments}

(1) Acid Pretreatment. Among all types of chemical pretreatments of biomass, dilute acid hydrolysis is reported as one of the most used and oldest method. The solubilization of hemicellulose occurs at high temperatures, or at high concentrated acid, releasing pentose sugars $[14,63]$ and facilitating the enzymatic hydrolysis of remaining substrate (cellulignin) [61]. The most commonly used acid is $\mathrm{H}_{2} \mathrm{SO}_{4}$, where its contact with biomass promotes hemicellulose breakdown in xylose and other sugars [14]. However, other acids such as $\mathrm{HCl}$ [64], phosphoric acid [65], nitric acid [66], and oxalic acid [67] have also shown promising results. The conditions of the process usually can be performed at temperatures among $120-180^{\circ} \mathrm{C}$ and residence times ranging 15-60 $\min [63]$.

One advantage of the acid pretreatment process is the operation at low and medium temperatures and consequently decreasing of energy costs [68]. However, in high concentration of acid problems can occur with equipment corrosion and expensive costs of maintenance [63], and also after this pretreatment, it is necessary to neutralize the hydrolysate before fermentations [14]. Another disadvantage of this process is the possibility of formation of other byproducts that are considered inhibitory to microbial fermentation, like furans, furfural, carboxylic acids, formic levulinic and acetic acids, and phenolic compounds. Therefore, a detoxification step is required to remove these inhibitory compounds to increase the fermentability of hydrolysates [69].

To calculate the efficiency of acid hydrolysis, factors like temperature, reaction time and acid concentration must be considered [70]. Overend and Chornet [71] developed an equation that involves the temperature and reaction time, indicating the severity of the pretreatment by combined severity factor (CSF):

$$
\mathrm{CSF}=t_{\exp }\left[\frac{\left(T-T_{\text {ref }}\right)}{14.75}\right],
$$

where $t$ is the residence time ( $\mathrm{min}) ; T$ is the temperature $\left({ }^{\circ} \mathrm{C}\right)$, and $T_{\text {ref }}$ is the reference temperature, usually set to $100^{\circ} \mathrm{C}$.

(2) Alkaline Pretreatment. Alkaline pretreatment is a delignification process, in which a significant amount of hemicellulose is also solubilized. It employs various bases, including sodium hydroxide, calcium hydroxide (lime), potassium hydroxide, ammonia hydroxide, and sodium hydroxide in combination with hydrogen peroxide or others [72]. The action mechanism of alkaline hydrolysis is believed to be saponification of intermolecular ester bonds crosslinking xylan hemicelluloses and other components [44]. This process utilizes lower temperatures and pressures than other pretreatment technologies; however, pretreatment times are on the order of hours or days [72]. Compared with acidbased pretreatment processes, alkaline processes causes less sugar degradation, and many of the caustic salts can be recovered and/or regenerated [43].

Alkaline pretreatment of lignocellulosic materials causes swelling, leading to an increase in internal surface area, decrease in the degree of polymerization and crystallinity, separation of structural linkages between lignin and carbohydrates, and disruption of the lignin structure [72] making cellulose and hemicellulose available for the enzymatic degradation [47].

The effectiveness of alkaline pretreatment varies, depending on the substrate and treatment conditions. In general, alkaline pretreatment is more effective on hardwood, herbaceous crops, and agricultural residues with low lignin content than softwood with high lignin content [72]. The end residue (mainly cellulose) can be used to produce either paper or cellulose derivatives [47] or the sugars generation upon enzymatic hydrolysis which can eventually be used for ethanol production. Reactor costs are lower than those for acid technologies. However, the use of these more expensive salts in high concentrations is a significant disadvantage that raises environmental concerns and may lead to prohibitive recycling, wastewater treatment, and residual handling costs $[59,72]$.

(3) Oxidative Delignification. Oxidative delignification process causes the delignification and the chemical swelling of the cellulose improving enzymatic saccharification significantly [73]. In this process, the lignin degradation is catalyzed by the peroxidase enzyme with the presence of 
$\mathrm{H}_{2} \mathrm{O}_{2}$ [44]. The oxidative delignification has been successfully operated in a continuous flow operation at high biomass loading (approximately $40 \%$ solids) and low $\mathrm{H}_{2} \mathrm{O}_{2}$ loading; though it is still a relatively less explored method compared to other thermochemical pretreatments [74]. This pretreatment method has been applied to a large variety of biomass such as corn stover, barley straw, wheat straw, bamboo, rice straw, and sugarcane bagasse [74].

(4) Ozonolysis. Ozone can be used to degrade the lignin and hemicellulose fractions from lignocellulosic materials such as wheat straw, bagasse, peanut, pine, cotton straw, and poplar sawdust [43]. Ozone is a powerful oxidant, soluble in water and is readily available. It is highly reactive towards the compounds incorporating conjugated double bonds and functional groups with high electron densities. Therefore, the most likely biomass constituent to be oxidized is lignin due to its high content of $\mathrm{C}=\mathrm{C}$ bounds [75].

Ozonolysis pretreatment has the advantages of effectively removal of lignin, it does not produce toxic residues for the downstream processes, and the reactions are carried out at ambient temperature and pressure [76]. However, a large amount of ozone is required, making the process expensive [44]. Furthermore, the fact that ozone can be easily decomposed by using a catalytic bed or increasing the temperature means that processes can be designed to minimize environmental pollution [43].

(5) Organosolv. Organosolv process seems one of the most promising methods for the pretreatment of lignocellulosics materials [77]. During this process, strong inorganic acid acts as a catalyst, promoting the breakdown of lignin-lignin and carbohydrates-lignin bonds from the biomass [38]. When the lignin is removed, the superficial area and volume of the material are also increased considerably, facilitating the enzyme accessibility and consequently improving the efficiency of the process to achieve fermentable sugars [78].

The organosolv process uses fewer amounts of chemicals to neutralize the hydrolyzate and generates few amounts of wastes compared with other similar process [61]. Chemicals such as $\mathrm{NaOH}$ or $\mathrm{Na}_{2} \mathrm{SO}_{3}$ could be used as catalyst [79]. High efficiency for lignin removal coupled with the high pressure of carbon dioxide has been observed using this process [80].

(6) Wet Oxidation. The wet oxidation process occurs in the presence of oxygen or catalyzed air, where the most used catalyst is the sodium carbonate [81]. Wet oxidation allows obtaining high yields of biomass conversion into monosaccharides with low formation of furan and phenolic aldehydes. In the wet oxidation process, the delignification is reported with the increasing of aliphatic acids. This pretreatment is considered expensive [81]. The major advantage of this pretreatment is the combination with alkalis where it is possible to achieve released sugars without generation of furfural and 5-hydroxymethylfurfural, undesirable compounds for fermentations [82].
5.1.4. Biological Pretreatment. Biological pretreatment is the alternative to chemical pretreatment to alter the structure of lignocellulosic materials. Generally, wood degrading microorganisms like bacteria and brown rot, white rot, and soft rot fungi are employed in the biological pretreatment [72]. This method provides degradation of lignin and hemicellulose making the biomass more amenable to enzyme digestion [47].

The most effective microorganism for biological pretreatment of lignocellulosic materials is white rot fungi [47]. These microorganisms degrade lignin through the action of lignin-degrading enzymes such as peroxidases and laccase [43]. Brown rot fungi mainly attack cellulose, while white and soft rot fungi attack both cellulose and lignin [44].

This pretreatment is environmental friendly because of its low energy use and mild environmental conditions [59]. The main disadvantages, that is, low efficiency, considerable loss of carbohydrates, long residence time, requirement of careful control of growth conditions, and space restrain its applications. In addition, most ligninolytic microorganisms solubilize/consume not only lignin but also a considerable fraction of hemicellulose and cellulose [72]. To overcome these limitations, biological treatments can be used in combination with other treatments [59]. Wang et al. [83] combined fungal treatment with liquid hot water (LHW) to enhance the enzymatic hydrolysis of Populus tomentosa.

5.2. Enzymatic Hydrolysis of Cellulosic Fraction. The general concept of conversion of cellulosic fraction into fermentable sugars involves the pretreatment of the raw material followed by its enzymatic hydrolysis. Enzymatic hydrolysis is an ideal approach for degrading cellulose into reducing sugars because mild reaction conditions ( $\mathrm{pH}$ between $4.8-5.0$ and temperature between $45-50^{\circ} \mathrm{C}$ ) can be used; it does not present corrosion problems in the reactors and result in negligible by-products formation with high sugar yields. However, enzymatic hydrolysis depends on optimized conditions for maximal efficiency (hydrolysis temperature, time, $\mathrm{pH}$, enzyme loading, and substrate concentration) and suffers from end-product inhibition and biomass structural restraints $[84,85]$. To overcome the end-product inhibition and reducing the time, hydrolysis and fermentation can be combined, so-called simultaneous saccharification and fermentation (SSF) or simultaneous saccharification and cofermentation (SSCF).

The enzymatic hydrolysis of cellulosic fraction requires three classes of cellulolytic enzymes (cellulases): (1) endo- $\beta$ 1,4-glucanases (EG, E.C. 3.2.1.4) which attacks regions of low crystallinity in the cellulose fiber, creating free chain ends; (2) cellobiohydrolases or exoglucanase (CBH, E.C. 3.2.1.91) which degrades the molecule further by removing cellobiose units from the free chain-ends; (3) $\beta$-glucosidases (E.C. 3.2.1.21) which hydrolyses cellobiose to produce glucose [44]. To breakdown the hemicellulose, several enzymes such as xylanase, b-xylosidase, glucuronidase, acetylesterase, galactomannanase, and glucomannanase are required [84]. Cellulase enzymes when acting together with xylanases on 
delignified SB/SS exhibit a better yield due to the synergistic action of enzymes [86].

Both bacteria (Clostridium, Cellulomonas, Bacillus, Thermomonospora, Ruminococcus, Bacteriodes, Erwinia, Acetovibrio, Microbispora, and Streptomyces) and fungi (Sclerotium rolfsii, Phanenerochate chrysosporium and species of Trichoderma, Aspergillus, Schizophyllum and Penicillium) can produce cellulases for the hydrolysis of cellulosic materials [44, 84]. Amongst the cellulase producing microorganisms, Aspergillus and Trichoderma genera are the widely studied.

For ethanol production from cellulosic materials, removal of lignin improved significantly the substrate digestibility. Furthermore, due to the lower lignin content, enzyme loadings can be considerably reduced. However, extensive lignin removals by pretreatments add cost to the processes [85].

Although enzyme price has decreased due to intensive research to improve their production, enzymes loading during cellulose hydrolysis should be minimized because it also increases the cellulosic ethanol production costs. Thus, finding paths to reduce cellulase loadings would be particularly effective in lowering the process costs. The enzyme source has also a major effect on the hydrolysis efficiency. Therefore, understanding the interaction between cellulases and pretreated biomass is vital to effectively develop lowcost pretreatment and enzyme properties that can lead to competitive ethanol costs [85].

\subsection{Detoxification (Treatment) of Hemicellulosic Hydrolysates.} The main preoccupations in the pretreatment of lignocellulosic materials are to minimize the sugars degradation and subsequently minimize the formation of inhibitory compounds for microbial metabolism, limit the consumption of chemicals, energy and water, and the production of wastes [39]. The inhibitory compounds could be divided into four groups: (1) substances that are released by the hemicellulosic structure, such as acetic acid, which originates in the deacetylation of xylan; (2) phenolic compounds and other aromatic compounds derived from the partial degradation of lignin; (3) the furan derivatives, furfural and 5-hydroxymethylfurfural, resulting from the degradation of pentoses and hexoses, respectively; (4) metals like chromium, copper, iron, and nickel leached from the equipment [69]. These compounds individually as well as synergistically affect the physiology of fermenting microorganisms, therefore, it is essential to eliminate these inhibitory compounds or reduce their concentration to obtain the satisfactory product yields during microbial fermentation of lignocellulose hydrolysates [67].

A number of methods like evaporation; neutralization; use of membranes, ion exchange resins, and activated charcoal; enzymatic detoxification using laccases and peroxidases have been attempted to detoxify the hydrolysates aiming ethanol production. Considering that different lignocellulosic hydrolysates have different degrees of inhibition and that microorganisms have different inhibitor tolerances, the methods of detoxification change will depend on the source of the lignocellulosic hydrolysate and the microorganism being used [87]. Several detoxification methods are described in this overview and can be divided into physical, physicochemical, chemical, and biological treatments.

\subsubsection{Physical Treatments}

(1) Evaporation (Concentration). The concentration of hydrolysates by vacuum evaporation process is a physical detoxification method which reduces the volatile compounds concentration, including acetic acid, furfural and vanillin [87]. However, this treatment has the disadvantage of increasing the nonvolatile toxic compounds, as extractives [88].

(2) Use of Membranes. The use of membranes has several advantages over conventional extraction. Membrane adsorption prevents that the aqueous phase (hydrolysate) is mixed with organic phase (solvent) which is likely to be toxic to microorganisms [89]. The membranes have surface functional groups attached to their internal pores, which may eliminate metabolic inhibitors as acetic acid, 5-hydroxymethylfurfural, furfural, formic, levulinic and sulphuric acid [67].

\subsubsection{Physicochemical Treatments}

(1) Ion Exchange Resins. The ion exchange resins process has been reported as the most efficient detoxification method. It is known that this process remove lignin-derived inhibitors, acetic acid, and furfurals of hydrolysate, improving significantly the yield fermentation [67]. The main advantage of the use of ion exchange resins is that they can be regenerated and reused without affecting the efficiency of the treatment $[65,90]$. However, this method presents some disadvantages: the high pressure drop across the bed that tends to increase during operation due to media deformation; long processing time because of the slow pore diffusion; possible degradation of fragile biological product molecules, and it is difficult to scale-up [91]. The ion exchange resins process also leads to a significant loss of fermentable sugars after the process [67].

(2) Neutralization. Considering the low $\mathrm{pH}$ of the hydrolysates provided by acid hydrolysis, it is needed that the neutralization of the $\mathrm{pH}$ to be close to the fermentations conditions. In this step, phenolics and furfurals are removed due to precipitations [67]. The chemicals employed in the neutralization of hydrolysates are calcium hydroxide and sodium hydroxide. The addition of $\mathrm{Ca}(\mathrm{OH})_{2}$ generates precipitate of $\mathrm{CaSO}_{4}$; therefore, it is desirable to be removed by centrifugation, adding one more stage in the process. During the generation of precipitates it can offer problems in fermentation [92].

(3) Overliming. Among different types of detoxification, overliming is reported as the most used method [93]. This process consists in an increase of the $\mathrm{pH}$ of acid hydrolysate followed by reduction until a $\mathrm{pH}$ desirable to fermentations. The principle of this process is the precipitation of toxic components and the instability of some inhibitors at high $\mathrm{pH}$ [69]. This method showed high efficiency towards the removal of inhibitors and is being widely used [90, 94, 95]. 
This method has been considered promising and economic, revealing good efficiency for the removal of the furans compounds [67].

(4) Activated Charcoal. Activated charcoal adsorption is a widely used detoxification method which is considered a low cost and efficient for inhibitors compounds removal. This method removes mainly phenolics compounds and does not provide large changes in the fermentable sugars levels [90]. The ratio of charcoal and hydrolysates, $\mathrm{pH}$, time of contact, and temperature are the important factors for the improvement of this method $[88,96]$.

(5) Extraction with Organic Solvents. Due to large availability of inhibitors such as acetic acid, furfural, vanillin, 4-hydroxybenzoic acid, and low molecular weight phenolics, the solvent extraction has been considered an efficient method of detoxification. The most common solvents used in this process are ethyl acetate, chloroform, and trichloroethylene [97].

5.3.3. Biological Treatment. Biological method uses specific enzymes or microorganisms that act on the inhibitors compounds present in the hydrolysate and change them [87]. In contrast with physical and chemical detoxifications, biological detoxification represents an improvement because little waste is generated and could be performed directly in the fermentation vessel before fermentation [98]. This method is still more feasible, environmental friendly, with fewer side reactions and less energy requirements [99]; however, it presents a long process time [100].

The use of enzymes is a very studied and promising method. Laccase and peroxidase enzymes derived from white rot fungi have been found effective for the removal of phenolics compounds from lignocellulosic hydrolysates [99]. The detoxification mechanism of these enzymes probably involves oxidative polymerization of phenolic compounds of low molecular weight [88]; they catalyze the oxidation of substituted phenols, anilines, and aromatic thiols, at the expense of molecular oxygen [101]. The disadvantages of enzyme detoxification are long incubation time and high costs of enzymes; however it has the advantage that is usually conducted at mild conditions $(\mathrm{pH}$ 5.0, mesophilic temperature) [102].

The use of microorganism has also been applied to remove inhibitors compounds from lignocellulosic hydrolysates [87]. There are several microorganisms which can naturally assimilate inhibitory compounds, including yeasts, fungi, and bacteria [102]. Some microorganisms during incubation are able to release cellulase and hemicellulase and degrade only lignin, resulting in a lignocellulosic substrate which can be easily hydrolyzed into fermentable sugars with mild conditions and short time [99].

These microorganisms can effectively degrade lignin while retaining cellulose and hemicellulose in the substrate. This method can also be referred as in situ microbial delignification (ISMD). Recently, several microorganisms have shown their preference towards inhibitors by transforming their chemical nature and can be employed for detoxification of lignocellulose hydrolysates [99, 103]. The adaptation of a microorganism to a nondetoxified hydrolysate is another interesting alternative to replace the detoxification step. This method is based on successive fermentations using the microorganism of each experiment as the inoculum of the next one [88]. The use of adapted microorganisms not only reduces the detoxification cost but also avoids loss of fermentable sugars [102].

\subsection{Fermentation of Sugars from \\ Sugarcane Biomass into Ethanol}

5.4.1. Bioconversion of Hexose Sugars into Ethanol. Ethanol fermentation is a biological process in which sugars are converted by microorganisms to produce ethanol and $\mathrm{CO}_{2}$. Even though there are the existence of many methods and process to use lignocellulosic materials for ethanol production, however, it is still difficult to obtain economic ethanol from lignocellulosics [86].

The microorganism most commonly used in fermentation process is the yeasts and, among the yeasts, Saccharomyces cerevisiae is the preferred choice for ethanol fermentation [104]. This yeast can grow both on simple sugars, such as glucose, and on the disaccharide sucrose. Furthermore, the availability of a robust genetic transformation system of $S$. cerevisiae along with a long history of this microorganism in industrial fermentation processes makes it most desired microorganisms for ethanol production. S. cerevisiae has high resistance to ethanol, consumes significant amounts of substrate in adverse conditions, and shows high resistance to inhibitors present in the medium [105]. Unfortunately, xylose metabolism presents a unique challenge for $S$. cerevisiae to assimilate pentose sugars due to the absence of genes required for assimilation of these molecules [105].

There are three kinds of processes to produce ethanol from sugarcane bagasse (SB) and sugarcane straw (SS). The first process is called separate (or sequential) hydrolysis and fermentation (SHF) where hydrolysis of lignocellulosic material and ethanol fermentation is done separately. SB/SS is pretreated, and the pretreated material is enzymatically hydrolyzed separately to recover the sugars. The recovered sugar solution (hexose sugars) is then fermented with appropriate microorganism into ethanol. SHF is a little staggered process [21]. The other two kinds of processes are called simultaneous saccharification and fermentation (SSF) and simultaneous saccharification and cofermentation (SSCF), where both enzymatic hydrolysis and fermentation of released sugars into ethanol occur simultaneously making the overall process short $[21,86]$. In the SSF process, the glucose (from cellulose hydrolyzed) is fermented separately of pentoses (from hydrolysate) in a separate reactor, while that in the SSCF process, the fermentation of xylose and glucose occurs together in the same reactor $[21,86]$.

5.4.2. Bioconversion of Pentose Sugars into Ethanol. The maximum utilization of all sugar fractions is essential to obtain an economic and viable conversion technology for bioethanol production from sugarcane bagasse (SB) and sugarcane 
straw (SS). To obtain the desired ethanol yields from SB/SS hydrolysates, it is essential that the hemicellulose fraction should be fermented with same conversion rates as the cellulose fraction [104].

Hemicellulose hydrolysate typically contains primarily pentose sugars (xylose and arabinose) and some amounts of hexose sugars (mannose, glucose and galactose) [106, 107]. A variety of yeast, fungi, and bacteria are capable of assimilating pentose, but only a few are promising candidates for the efficient xylose fermentation into ethanol [106]. In yeasts, the assimilation of D-xylose follows the pathway where the sugar passes through a pool enzymatic to enter in the phosphopentose pathway [108]. There are several microorganisms capable of assimilating pentose sugars, but only few species are capable of assimilating sugars to produce ethanol at industrial scale. Microorganisms, such as Scheffersomyces stipitis (Pichia stipitis) [109], Candida guilliermondii, Candida shehatae, and Pachysolen tannophilus are able to assimilate pentose sugars by a reduction/oxidation pathway bioconversion of sugarcane bagasse/sugarcane straw hydrolysates under different cultivation conditions [110].

The process to assimilate pentose sugars consists in the xylose being converted to xylitol, by the action of Dxylose reductase (E.C. 1.1.1.21) and immediately oxidized by the action of xylitol dehydrogenase (E.C. 1.1.1.9), producing D-xylose-5-phosphate. Ribolosephosphate-3-epimerase (5.1.3.1), transaldolase (E.C. 2.2.1.2), and transketolase (E.C. 2.2.1.1) sequentially convert D-xylose-5-phosphate into glyceraldehyde-3-phosphate and fructose-6-phoshate by non-oxidative rearrangement resulting into the formation of ethanol by the Emden-Meyorhoff Pathway. NADPH must be regenerated through metabolic routes. The metabolic pathway of the arabinose is similar to the route shown by xylose, where aldose reductase mechanistically converts arabinose into L-arabitol. Through the action of L-arabitol dehydrogenase, L-arabitol is reduced to ethanol $[99,105]$. Recently published reviews have competently presented the important progress made for pentose sugars fermentation into ethanol $[99,110]$.

5.5. Distillation of Ethanol. Despite the downstream process being the highest energy consuming process during the ethanol production [111], the ethanol recovery from the fermented broth is necessary. The final medium is composed by water and ethanol (5-12 wt\%) [112]. The ethanol-water cannot be separated by conventional distillation processes because they form a nonideal mixture system [113]. The dehydration is sophisticated method because they form an azeotropic mixture with water (at $95.6 \mathrm{wt} \%$ at a temperature of $78.15^{\circ} \mathrm{C}$ ), which makes it impossible to separate in a single distillation column [112]. This way, the ethanol purification occurs in three steps: distillation, rectification, and dehydration. A high concentrated ethanol solution is obtained in the two first steps (about $92.4 \mathrm{wt} \%$ ), then the mixture is dehydrated in order to obtain ethanol anhydrous by a dehydration method. The dehydration can be realized by azeotropic distillation, extractive distillation, liquid-liquid extraction, adsorption, or some complex hybrid separation methods [112].

\section{Conclusion}

Sugarcane bagasse (SB) and sugarcane straw (SS) are the attractive second-generation renewable feedstock available in several countries like Brazil. This feedstock if used judiciously may provide the sustainable supply of drop-in ethanol, industrial enzymes, organics acids, single cell proteins, and so forth. However, a significant fraction of this biomass goes to industries for steam and electricity generation. The remaining fraction represents the ideal feedstock for the generation high-value commodities. Last three decades of vigorous developments in pretreatment technologies, microbial biotechnology, and downstream processing have made it reality to harness the sugarcane residues for the production of many products of commercial significance at large scale without jeopardizing the food/feed requirements. Biomass recalcitrance is a main challenge toward the successful exploitation of these residues. To overcome the biomass recalcitrance, pretreatment is an inevitable process to ameliorate the accessibility of carbohydrate for the subsequent enzymatic hydrolysis reaction to generate fermentable sugars. There are several robust pretreatment methods available; however, the ultimate choice for the selection of pretreatment process depends upon the effective delignification or hemicellulose removal, minimum generation of inhibitors, low sugar loss, time savings, being economic and causing less environmental pollution. The released sugars after enzymatic hydrolysis and hemicellulose depolymerization are converted into ethanol by the suitable ethnologic strain. In order to get desired ethanol yields, the ethnologic strains should have ability to utilize pentose and hexose sugars, inhibitor resistance, and high osmotolerance. The following ten requirements are pivotal in order to establish a long-term sustainable second-generation ethanol production process from sugarcane residues.

(1) Fullest utilization of SB and SS generated in the country for the better management.

(2) Selection of right pretreatment and detoxification strategy.

(3) In-house cellulase production and development of cellulolytic strains and ethanol producing strains from pentose and hexose sugars showing inhibitor resistance, ethanol tolerance, and faster sugar conversion rates.

(4) Process intensification: hydrolysis and fermentation together in one place.

(5) Cheap, fast, and effective ethanol distillation.

(6) Integration of bioethanol producing units with sugar/distilleries for the coutilization of machinery, reactors, and other equipment.

(7) Maximum by products utilization (lignin, furans, and yeast cell mass).

(8) Environmental protection. 
(9) Government subsidies to promote the renewable energy.

(10) Encouragement of private investments.

\section{Acknowledgments}

The authors are grateful to FAPESP, CAPES, and CNPq.

\section{References}

[1] C. R. Soccol, L. P. D. S. Vandenberghe, A. B. P. Medeiros et al., "Bioethanol from lignocelluloses: status and perspectives in Brazil," Bioresource Technology, vol. 101, no. 13, pp. 4820 4825, 2010.

[2] B. S. Dien, M. A. Cotta, and T. W. Jeffries, "Bacteria engineered for fuel ethanol production: current status," Applied Microbiology and Biotechnology, vol. 63, no. 3, pp. 258-266, 2003.

[3] "Conab (Companhia Nacional de Abastecimento-National Supply Company), 2012. Acompanhamento da Safra Brasileira de Cana-de-açúcar. Primeiro Levantamento da Safra 2012/2013," http://www.conab.gov.br/.

[4] "Conab (Companhia Nacional de Abastecimento-National Supply Company), 2012. Acompanhamento da Safra Brasileira de Grãos. Décimo Segundo Levantamento da Safra 2011/ 2012," http://www.conab.gov.br/.

[5] "Embrapa (Empresa Brasileira de Pesquisa AgropecuáriaBrazilian Agricultural Research Corporation), 2010. Produção Brasileira de Mandioca em 2010," http://www.embrapa .br/.

[6] R. C. L. B. Rodrigues, M. D. G. A. Felipe, J. B. Almeida E Silva, and M. Vitolo, "Response surface methodology for xylitol production from sugarcane bagasse hemicellulosic hydrolyzate using controlled vacuum evaporation process variables," Process Biochemistry, vol. 38, no. 8, pp. 1231-1237, 2003.

[7] "Cenbio (Centro Nacional em Referência de BiomassaBrazilian Reference Center on Biomass),” 2003, http://cenbio .iee.usp.br/.

[8] R. C. D. Cerqueira Leite, M. R. L. V. Leal, L. A. B. Cortez, W. M. Griffin, and M. I. Gaya Scandiffio, "Can Brazil replace 5\% of the 2025 gasoline world demand with ethanol?" Energy, vol. 34, no. 5, pp. 655-661, 2009.

[9] L. A. D. Paes and M. A. Oliveira, "Potential trash biomass of the sugar cane plant," in Biomass Power Generation. Sugarcane Bagasse and Trash, S. J. Hassuani, M. L. R. V. Leal, and I. C. Macedo, Eds., p. 19, PNUD and CTC, Piracicaba, Brazil, 1st edition, 2005.

[10] M. A. T. Neto, "Characterization of sugarcane trash and bagasse," in Biomass Power Generation. Sugarcane Bagasse and Trash, S. J. Hassuani, M. L. R. V. Leal, and I. C. Macedo, Eds., p. 24, PNUD and CTC, Piracicaba, Brazil, 1st edition, 2005.

[11] O. Triana, M. Leonard, F. Saavedra, I. C. Acan, O. L. Garcia, and A. Abril, Atlas of Sugarcane Bagasse, Geplacea and ICIDCA, México, 1990.

[12] A. V. Ensinas, M. Modesto, S. A. Nebra, and L. Serra, "Reduction of irreversibility generation in sugar and ethanol production from sugarcane," Energy, vol. 34, no. 5, pp. 680-688, 2009.

[13] M. J. R. Mutton, "Reflex of raw material quality in fermentative process," in Proceedings of the 14th Workshop-Ethanol
Production: Raw Material Quality, Engineering School of Lorena, University of São Paulo, São Paulo, Brazil, 2008.

[14] N. Mosier, C. Wyman, B. Dale et al., "Features of promising technologies for pretreatment of lignocellulosic biomass," Bioresource Technology, vol. 96, no. 6, pp. 673-686, 2005.

[15] G. J. M. Rocha, C. Martin, I. B. Soares, A. M. Souto Maior, H. M. Baudel, and C. A. M. de Abreu, "Dilute mixed-acid pretreatment of sugarcane bagasse for ethanol production," Biomass and Bioenergy, vol. 35, no. 1, pp. 663-670, 2011.

[16] D. Fengel and G. Wegener, Wood Chemistry, Ultrastructure, Reactions, Walter de Gruyter, Berlin, Germany, 1989.

[17] A. Singh and P. Mishra, "Microbial pentose utilization," in Current Applications in Biotechnology, vol. 33 of Progress in Industrial Microbiology, 1995.

[18] H. Boussarsar, B. Rogé, and M. Mathlouthi, "Optimization of sugarcane bagasse conversion by hydrothermal treatment for the recovery of xylose," Bioresource Technology, vol. 100, no. 24, pp. 6537-6542, 2009.

[19] L. Canilha, V. T. O. Santos, G. J. M. Rocha et al., "A study on the pretreatment of a sugarcane bagasse sample with dilute sulfuric acid," Journal of Industrial Microbiology and Biotechnology, vol. 38, pp. 1467-1475, 2011.

[20] R. C. Kuhad, A. Singh, and K. E. Eriksson, "Microorganisms and enzymes involved in the degradation of plant fiber cell walls," Advances in Biochemical Engineering and Biotechnology, vol. 57, pp. 45-125, 1997.

[21] M. J. Taherzsadeh and K. Karimi, "Enzymatic-based hydrolysis processes for ethanol from lignocellulosic materials: a review," Bioresources, vol. 2, pp. 707-738, 2007.

[22] A. R. Gonçalves and M. A. Soto-Oviedo, "Production of chelating agents through the enzymatic oxidation of Acetosolv sugarcane bagasse lignin," Applied Biochemistry and Biotechnology A, vol. 98-100, pp. 365-371, 2002.

[23] D. Stewart, "Lignin as a base material for materials applications: chemistry, application and economics," Industrial Crops and Products, vol. 27, no. 2, pp. 202-207, 2008.

[24] V. Fierro, V. Torné-Fernández, D. Montané, and A. Celzard, "Adsorption of phenol onto activated carbons having different textural and surface properties," Microporous and Mesoporous Materials, vol. 111, no. 1-3, pp. 276-284, 2008.

[25] H. L. Chum, S. K. Parker, D. A. Feinberg et al., The Economic Contribution of Lignin to Ethanol Production from Biomass, Solar Energy Research Institute, Golden, Colo, USA, 1985.

[26] P. Benar, Polpação acetosolv de bagaço de cana e madeira de eucalipto (Acetosolv pulping of bagasse and Eucaliptus wood) [M.S. thesis], Chemical Institute, Campinas University, São Paulo, Brazil, 1992.

[27] A. P. Pitarelo, Avaliação da susceptibilidade do bagaço e da palha de cana-de-açúcar à bioconversão via pré-tratamento a vapor e hidrólise enzimática (Evaluation of susceptibility of sugarcane bagasse and straw on the bioconversion by steamexplosion and enzymatic hydrolysis) [M.S. thesis], Federal Univesity of Paraná, Paraná, Brazil, 2007.

[28] A. S. da Silva, H. Inoue, T. Endo, S. Yano, and E. P. S. Bon, "Milling pretreatment of sugarcane bagasse and straw for enzymatic hydrolysis and ethanol fermentation," Bioresource Technology, vol. 101, no. 19, pp. 7402-7409, 2010.

[29] M. Brienzo, A. F. Siqueira, and A. M. F. Milagres, "Search for optimum conditions of sugarcane bagasse hemicellulose extraction," Biochemical Engineering Journal, vol. 46, no. 2, pp. 199-204, 2009. 
[30] S. C. Rabelo, H. Carrere, R. Maciel Filho, and A. C. Costa, "Production of bioethanol, methane and heat from sugarcane bagasse in a biorefinery concept," Bioresource Technology, vol. 102, no. 17, pp. 7887-7895, 2011.

[31] A. Pandey, C. R. Soccol, P. Nigam, and V. T. Soccol, "Biotechnological potential of agro-industrial residues. I: sugarcane bagasse," Bioresource Technology, vol. 74, no. 1, pp. 69-80, 2000.

[32] R. Hatfield and R. S. Fukushima, "Can lignin be accurately measured?” Crop Science, vol. 45, no. 3, pp. 832-839, 2005.

[33] L. A. D. Paes and S. J. Hassuani, "Potential trash and biomass of the sugarcane plantation, including trash recovery factors," in Biomass Power Generation. Sugarcane Bagasse and Trash, S. J. Hassuani, M. L. R. V. Leal, and I. C. Macedo, Eds., p. 19, PNUD and CTC, Piracicaba, Brazil, 1st edition, 2005.

[34] R. Y. Moriya, Uso de xilanases e lacases de microrganismos no branqueamento de polpas organosolv de palha de cana-deaçúcar e estudo dos derivados celulósicos obtidos (Use of microbial xylanases and laccases in the bleaching of organosolv pulps from sugarcane straw and study of the cellulosic derivatives obtained) [Ph.D. thesis], University of São Paulo, Engineering School of Lorena, São Paulo, Brazil, 2007.

[35] M. B. W. Saad, L. R. M. Oliveira, R. G. Cândido, G. Quintana, G. J. M. Rocha, and A. R. Gonçalves, "Preliminary studies on fungal treatment of sugarcane straw for organosolv pulping," Enzyme and Microbial Technology, vol. 43, no. 2, pp. 220-225, 2008.

[36] S. M. Luz, A. R. Gonçalves, A. P. Del'Arco Jr., A. L. Leão, P. M. C. Ferrão, and G. J. M. Rocha, "Thermal properties of polypropylene composites reinforced with different vegetable fibers," Advanced Materials Research, vol. 123-125, pp. 11991202, 2010.

[37] S. M. Costa, P. G. Mazzola, J. C. A. R. Silva, R. Pahl, A. Pessoa Jr., and S. A. Costa, "Use of sugar cane straw as a source of cellulose for textile fiber production," Industrial Crops and Products, vol. 42, pp. 189-194, 2013.

[38] M. T. Holtzapple and A. E. Humphrey, "The effect of organosolv pretreatment on the enzymatic hydrolysis of poplar," Biotechnology and Bioengineering, vol. 26, no. 7, pp. 670-676, 1984.

[39] A. Margeot, B. Hahn-Hagerdal, M. Edlund, R. Slade, and F. Monot, "New improvements for lignocellulosic ethanol," Current Opinion in Biotechnology, vol. 20, no. 3, pp. 372-380, 2009.

[40] A. K. Chandel, G. Calvet, E. C. Giese, J. Reis, and S. S. Silva, "Statistical optimization of dual acid-base pretreatment of sugarcane bagasse improves the enzymatic hydrolysis into fermentable sugars," in Proceedings of the Workshop on Second Generation of Bioethanol: Enzymatic Hydrolysis, Campinas, Brazil, November 2011.

[41] G. Y. S. Mtui, "Recent advances in pretreatment of lignocellulosic wastes and production of value added products," African Journal of Biotechnology, vol. 8, no. 8, pp. 1398-1415, 2009.

[42] A. K. Chandel, E. C. Chan, R. Rudravaram, M. L. Narasu, L. V. Rao, and P. Ravinda, "Economics and environmental impact of bioethanol production technologies: an appraisal," Biotechnology and Molecular Biology Reviews, vol. 2, pp. 1432, 2007.

[43] P. Kumar, D. M. Barrett, M. J. Delwiche, and P. Stroeve, "Methods for pretreatment of lignocellulosic biomass for efficient hydrolysis and biofuel production," Industrial and Engineering Chemistry Research, vol. 48, no. 8, pp. 3713-3729, 2009.
[44] Y. Sun and J. Cheng, "Hydrolysis of lignocellulosic materials for ethanol production: a review," Bioresource Technology, vol. 83, no. 1, pp. 1-11, 2002.

[45] H. Inoue, S. Yano, T. Endo, T. Sakaki, and S. Sawayama, "Combining hot-compressed water and ball milling pretreatments to improve the efficiency of the enzymatic hydrolysis of eucalyptus," Biotechnology for Biofuels, vol. 1, article 2, 2008.

[46] A. Hideno, H. Inoue, K. Tsukahara et al., "Wet disk milling pretreatment without sulfuric acid for enzymatic hydrolysis of rice straw," Bioresource Technology, vol. 100, no. 10, pp. 2706-2711, 2009.

[47] N. Sarkar, S. K. Ghosh, S. Bannerjee, and K. Aikat, "Bioethanol production from agricultural wastes: an overview," Renewable Energy, vol. 37, no. 1, pp. 19-27, 2012.

[48] K. Açikalin, F. Karaca, and E. Bolat, "Pyrolysis of pistachio shell: effects of pyrolysis conditions and analysis of products," Fuel, vol. 95, pp. 169-177, 2012.

[49] F. A. Agblevor, S. Besler, and A. E. Wiselogel, "Fast pyrolysis of stored biomass feedstocks," Energy \& Fuels, vol. 9, no. 4, pp. 635-640, 1995.

[50] P. Binod, K. Satyanagalakshmi, R. Sindhu, K. U. Janu, R. K. Sukumaran, and A. Pandey, "Short duration microwave assisted pretreatment enhances the enzymatic saccharification and fermentable sugar yield from sugarcane bagasse," Renewable Energy, vol. 37, no. 1, pp. 109-116, 2012.

[51] I. Balcu, C. A. Macarie, A. E. Segneanu, and R. Oana, "Combined microwave-acid pretreatment of the biomass," in Progress in Biomass and Bioenergy Production, S. S. Shaukai, Ed., pp. 223-238, In Tech, Rijeka, Croatia, 2011.

[52] D. R. Keshwani, Microwave pretreatment of switchgrass for bioethanol production [Ph.D. thesis], Philosophy Biological and Agricultural Engineering, Raleigh, NC, USA, 2009.

[53] J. Xiong, J. Ye, W. Z. Liang, and P. M. Fan, "Influence of microwave on the ultrastructure of cellulose," Journal of South China University Technology, vol. 28, pp. 84-89, 2000.

[54] X. Lu, B. Xi, Y. Zhang, and I. Angelidaki, "Microwave pretreatment of rape straw for bioethanol production: focus on energy efficiency," Bioresource Technology, vol. 102, no. 17, pp. 7937-7940, 2011.

[55] E. Chornet and R. P. Overend, "Phenomenological kinetics and reaction engineering aspects of steam/aqueous treatments," in Steam Explosion Techniques: Fundamentals and Industrial Applications, B. Focher, A. Marzetti, and V. Crescenzi, Eds., pp. 21-58, Goran and Breach Science Publishers, Philadelphia, Pa, USA, 1991.

[56] W. E. Kaar, C. V. Gutierrez, and C. M. Kinoshita, "Steam explosion of sugarcane bagasse as a pretreatment for conversion to ethanol," Biomass and Bioenergy, vol. 14, no. 3, pp. 277287, 1998.

[57] V. B. Agbor, N. Cicek, R. Sparling, A. Berlin, and D. B. Levin, "Biomass pretreatment: fundamentals toward application," Biotechnology Advances, vol. 29, pp. 675-685, 2011.

[58] B. Bals, C. Wedding, V. Balan, E. Sendich, and B. Dale, "Evaluating the impact of ammonia fiber expansion (AFEX) pretreatment conditions on the cost of ethanol production," Bioresource Technology, vol. 102, no. 2, pp. 1277-1283, 2011.

[59] C. N. Hamelinck, G. van Hooijdonk, and A. P. C. Faaij, "Ethanol from lignocellulosic biomass: techno-economic performance in short-, middle- and long-term," Biomass and Bioenergy, vol. 28, no. 4, pp. 384-410, 2005.

[60] W. S. Cardoso, F. A. Santos, A. M. Mota, F. D. Tardin, S. T. Resende, and J. H. Queiroz, "Pré-Tratamentos de Biomassa 
para Produção de Etanol de Segunda Geração," Revista Analytica, vol. 56, pp. 64-76, 2012.

[61] M. J. Taherzadeh and K. Karimi, "Pretreatment of lignocellulosic wastes to improve ethanol and biogas production: a review," International Journal of Molecular Sciences, vol. 9, no. 9, pp. 1621-1651, 2008.

[62] N. S. Mosier, R. Hendrickson, R. Dreschel et al., "Principles and economics of pretreating cellulose in water for ethanol production," in Proceedings of the 225th American Chemical Society Meeting, vol. 103, BIOT Division, New Orleans, La, USA, 2003.

[63] P. Alvira, E. Tomás-Pejó, M. Ballesteros, and M. J. Negro, "Pretreatment technologies for an efficient bioethanol production process based on enzymatic hydrolysis: a review," Bioresource Technology, vol. 101, no. 13, pp. 4851-4861, 2010.

[64] P. Laopaiboon, A. Thani, V. Leelavatcharamas, and L. Laopaiboon, "Acid hydrolysis of sugarcane bagasse for lactic acid production," Bioresource Technology, vol. 101, no. 3, pp. 1036-1043, 2010.

[65] W. Carvalho, M. A. Batista, L. Canilha, J. C. Santos, A. Converti, and S. S. Silva, "Sugarcane bagasse hydrolysis with phosphoric and sulfuric acids and hydrolysate detoxification for xylitol production," Journal of Chemical Technology and Biotechnology, vol. 79, no. 11, pp. 1308-1312, 2004.

[66] A. Rodríguez-Chong, J. A. Ramírez, G. Garrote, and M. Vázquez, "Hydrolysis of sugar cane bagasse using nitric acid: a kinetic assessment," Journal of Food Engineering, vol. 61, no. 2, pp. 143-152, 2004.

[67] A. K. Chandel, S. S. Silva, and O. V. Singh, "Detoxification of lignocellulosic hydrolysates for improved bioethanol production," in Biofuel Production-Recent Developments and Prospects, M. A. S. Bernardes, Ed., pp. 225-246, In Tech, Rijeka, Croatia, 2011.

[68] F. M. Gírio, C. Fonseca, F. Carvalheiro, L. C. Duarte, S. Marques, and R. Bogel-Łukasik, "Hemicelluloses for fuel ethanol: a review," Bioresource Technology, vol. 101, no. 13, pp. 47754800, 2010.

[69] E. Palmqvist and B. Hahn-Hägerdal, "Fermentation of lignocellulosic hydrolysates. II: inhibitors and mechanisms of inhibition," Bioresource Technology, vol. 74, no. 1, pp. 25-33, 2000.

[70] I. K. Kapdan, F. Kargi, and R. Oztekin, "Effects of operating parameters on acid hydrolysis of ground wheat starch: maximization of the sugar yield by statistical experiment design," Starch-Stärke, vol. 63, no. 5, pp. 311-318, 2011.

[71] R. P. Overend and E. Chornet, "Fractionation of lignocellulosics by steam aqueous pretreatments," Philosophical Transactions of the Royal Society, vol. 321, pp. 523-536, 1987.

[72] Y. Zheng, Z. Pan, and R. Zhang, "Overview of biomass pretreatment for cellulosic production," International Journal of Agricultural and Biological Engineering, vol. 2, pp. 51-68, 2009.

[73] Y. Yamashita, M. Shono, C. Sasaki, and Y. Nakamura, "Alkaline peroxide pretreatment for efficient enzymatic saccharification of bamboo," Carbohydrate Polymers, vol. 79, no. 4, pp. 914-920, 2010.

[74] G. Banerjee, S. Car, J. S. Scott-Craig, D. B. Hodge, and J. D. Walton, "Alkaline peroxide pretreatment of corn stover: effects of biomass, peroxide, and enzyme loading and composition on yields of glucose and xylose," Biotechnology for Biofuels, vol. 4, article 16, 2011.

[75] M. T. García-Cubero, G. González-Benito, I. Indacoechea, M. Coca, and S. Bolado, "Effect of ozonolysis pretreatment on enzymatic digestibility of wheat and rye straw," Bioresource Technology, vol. 100, no. 4, pp. 1608-1613, 2009.

[76] P. F. Vidal and J. Molinier, "Ozonolysis of lignin-improvement of in vitro digestibility of poplar sawdust," Biomass, vol. 16, no. 1, pp. 1-17, 1988.

[77] R. El Hage, N. Brosse, L. Chrusciel, C. Sanchez, P. Sannigrahi, and A. Ragauskas, "Characterization of milled wood lignin and ethanol organosolv lignin from miscanthus," Polymer Degradation and Stability, vol. 94, pp. 1632-1638, 2009.

[78] B. W. Koo, H. Y. Kim, N. Park, S. M. Lee, H. Yeo, and I. G. Choi, "Organosolv pretreatment of Liriodendron tulipifera and simultaneous saccharification and fermentation for bioethanol production," Biomass and Bioenergy, vol. 35, no. 5, pp. 1833-1840, 2011.

[79] D. S. Ruzene, A. R. Gonçalves, J. A. Teixeira, and M. T. Pessoa De Amorim, "Carboxymethylcellulose obtained by ethanol/water organosolv process under acid conditions," Applied Biochemistry and Biotechnology, vol. 137-140, no. 112, pp. 573-582, 2007.

[80] D. Pasquini, M. T. B. Pimenta, L. H. Ferreira, and A. A. D. S. Curvelo, "Extraction of lignin from sugar cane bagasse and Pinus taeda wood chips using ethanol-water mixtures and carbon dioxide at high pressures," Journal of Supercritical Fluids, vol. 36, no. 1, pp. 31-39, 2005.

[81] F. Carvalheiro, L. C. Duarte, and F. M. Gírio, "Hemicellulose biorefineries: a review on biomass pretreatments," Journal of Scientific and Industrial Research, vol. 67, no. 11, pp. 849-864, 2008.

[82] A. B. Bjerre, A. B. Olesen, and T. Fernqvist, "Pretreatment of wheat straw using combined wet oxidation and alkaline hydrolysis resulting in convertible cellulose and hemicellulose," Biotechnology and Bioengineering, vol. 49, pp. 568-577, 1996.

[83] W. Wang, T. Yuan, K. Wang, B. Cui, and Y. Dai, "Combination of biological pretreatment with liquid hot water pretreatment to enhance enzymatic hydrolysis of Populustomentosa," Bioresource Technology, vol. 107, pp. 282-286, 2012.

[84] S. J. B. Duff and W. D. Murray, "Bioconversion of forest products industry waste cellulosics to fuel ethanol: a review," Bioresource Technology, vol. 55, no. 1, pp. 1-33, 1996.

[85] A. M. F. Milagres, W. Carvalho, and A. L. Ferraz, "Topochemistry, porosity and chemical composition affecting enzymatic hydrolysis of lignocellulosic materials," in Routes to Cellulosic Ethanol, M. S. Buckeridge and G. H. Goldman, Eds., p. 53, Springer, Berlin, Germany, 2011.

[86] E. C. Giese, A. K. Chandel, I. S. Oliveira, and S. S. Silva, "Prospects for the bioethanol production from sugarcane feedstock: focus on Brazil," in Sugarcane: Production, Cultivation and Uses, J. F. Gonçalves and K. D. Correa, Eds., Nova Science Publishers, New York, NY, USA, 2011.

[87] R. Anish and M. Rao, "Bioethanol from lignocellulosic biomass part III hydrolysis and fermentation," in Handbook of Plant-Based Biofuels, A. Pandey, Ed., pp. 159-173, CRC Press, Portland, Ore, USA, 2009.

[88] S. I. Mussatto and I. C. Roberto, "Alternatives for detoxification of diluted-acid lignocellulosic hydrolyzates for use in fermentative processes: a review," Bioresource Technology, vol. 93, no. 1, pp. 1-10, 2004.

[89] D. L. Grzenia, D. J. Schell, and S. R. Wickramasighe, "Membrane extraction for detoxification of biomass hydrolysates," Bioresource Technology, vol. 111, pp. 248-254, 2012.

[90] L. Canilha, W. Carvalho, M. Giulietti, M. D. G. A. Felipe, and J. B. A. E. Silva, "Clarification of a wheat straw-derived medium with ion-exchange resins for xylitol crystallization," 
Journal of Chemical Technology and Biotechnology, vol. 83, no. 5, pp. 715-721, 2008.

[91] N. O. Nilvebrant, A. Reimann, S. Larsson, and L. J. Jönsson, "Detoxification of lignocellulose hydrolysates with ion-exchange resins," Applied Biochemistry and Biotechnology A, vol. 91-93, pp. 35-49, 2001.

[92] E. Palmqvist and B. Hahn-Hägerdal, "Fermentation of lignocellulosic hydrolysates. I: inhibition and detoxification," Bioresource Technology, vol. 74, no. 1, pp. 17-24, 2000.

[93] J. J. Zhu, Q. Yong, Y. Xu, and S. Y. Yu, "Comparative detoxification of vacuum evaporation/steam stripping combined with overliming on corn stover prehydrolyzate," in Proceedings of the International Conference on Energy and Environment Technology (ICEET '09), vol. 3, pp. 240-243, October 2009.

[94] W. Carvalho, L. Canilha, and S. S. Silva, "Semi-continuous xylose-to-xylitol bioconversion by Ca-alginate entrapped yeast cells in a stirred tank reactor," Bioprocess and Biosystems Engineering, vol. 31, no. 5, pp. 493-498, 2008.

[95] F. A. F. Antunes, T. S. S. Milessi, I. Oliveira, A. K. Chandel, and S. S. Silva, "Characterization of sugarcane bagasse hemicellulosic hydrolysate after detoxification with overliming and activated charcoal," in Proceedings of the 20th European Biomass Conference and Exhibition, Milan, Italy, 2012.

[96] A. Converti, J. M. Domínguez, P. Perego, S. S. Da Silva, and M. Zilli, "Wood hydrolysis and hydrolysate detoxification for subsequent xylitol production," Chemical Engineering and Technology, vol. 23, no. 11, pp. 1013-1020, 2000.

[97] M. Cantarella, L. Cantarella, A. Gallifuoco, A. Spera, and F. Alfani, "Comparison of different detoxification methods for steam-exploded poplar wood as a substrate for the bioproduction of ethanol in SHF and SSF," Process Biochemistry, vol. 39, no. 11, pp. 1533-1542, 2004.

[98] Z. Hou-Rui, Q. Xiang-Xiang, S. S. Silva et al., "Novel isolates for biological detoxification of lignocellulosic hydrolysate," Applied Biochemistry and Biotechnology, vol. 152, no. 2, pp. 199-212, 2009.

[99] A. K. Chandel, G. Chandrasekhar, K. Radhika, R. Ravinder, and P. Ravindra, "Bioconversion of pentose sugars into ethanol: a review and future directions," Biotechnology and Molecular Biology Reviews, vol. 6, pp. 8-20, 2011.

[100] B. Yang and C. E. Wyman, "Pretreatment: the key to unlocking low-cost cellulosic ethanol," Biofuels, Bioproducts and Biorefining, vol. 2, no. 1, pp. 26-40, 2008.

[101] A. D. Moreno, D. Ibarra, J. L. Férnandez, and M. Ballesteros, "Different laccase detoxification strategies for ethanol production from lignocellulosic biomass by the thermotolerant yeast Kluyveromyces marxianus CECT, 10875," Bioresource Technology, vol. 106, pp. 101-109, 2012.

[102] W. Parawira and M. Tekere, "Biotechnological strategies to overcome inhibitors in lignocellulose hydrolysates for ethanol production: review," Critical Reviews in Biotechnology, vol. 31, no. 1, pp. 20-31, 2011.

[103] B. G. Fonseca, R. D. O. Moutta, F. D. O. Ferraz et al., "Biological detoxification of different hemicellulosic hydrolysates using Issatchenkia occidentalis CCTCC M 206097 yeast," Journal of Industrial Microbiology and Biotechnology, vol. 38, no. 1, pp. 199-207, 2011.

[104] Y. Lin and S. Tanaka, "Ethanol fermentation from biomass resources: current state and prospects," Applied Microbiology and Biotechnology, vol. 69, no. 6, pp. 627-642, 2006.

[105] R. E. Hector, J. A. Mertens, M. J. Bowman, N. N. Nichols, M. A. Cotta, and S. R. Hughes, "Saccharomyces cerevisiae engineered for xylose metabolism requires gluconeogenesis and the oxidative branch of the pentose phosphate pathway for aerobic xylose assimilation," Yeast, vol. 28, pp. 645-660, 2011.

[106] L. K. Singh, G. Chaudhary, C. B. Majumder, and S. Ghosh, "Utilization of hemicellulosic fraction of lignocellulosic material for bioethanol production," Advances in Applied Science Research, vol. 2, no. 5, pp. 508-521, 2011.

[107] J. Shen and C. E. Wyman, "A novel mechanism and kinetic model to explain enhanced xylose yields from dilute sulfuric acid compared to hydrothermal pretreatment of corn stover," Bioresource Technology, vol. 102, pp. 9111-9120, 2011.

[108] M. Bettiga, B. Hahn-Hägerdal, and M. F. Gorwa-Grauslund, "Comparing the xylose reductase/xylitol dehydrogenase and xylose isomerase pathways in arabinose and xylose fermenting Saccharomyces cerevisiae strains," Biotechnology for Biofuels, vol. 1, article 16, 2008.

[109] C. P. Kurtzman and M. Suzuki, "Phylogenetic analysis of ascomycete yeasts that form coenzyme Q-9 and the proposal of the new genera Babjeviella, Meyerozyma, Millerozyma, Priceomyces, and Scheffersomyces," Mycoscience, vol. 51, no. 1, pp. 2-14, 2010.

[110] R. C. Kuhad, R. Gupta, Y. P. Khasa, A. Singh, and Y. H. P. Zhang, "Bioethanol production from pentose sugars: current status and future prospects," Renewable and Sustainable Energy Reviews, vol. 15, pp. 4950-4962, 2011.

[111] M. R. L. V. Leal, "Ethanol production from cane resources," in Bioenergy for Sustainable Development and International Competitiveness, F. X. Johnson and V. Seebaluck, Eds., pp. 126-157, Routledge, Abingdon, UK, 2012.

[112] H. J. Huang, S. Ramaswamy, U. W. Tschirner, and B. V. Ramarao, "A review of separation technologies in current and future biorefineries," Separation and Purification Technology, vol. 62, no. 1, pp. 1-21, 2008.

[113] P. W. Madson, "Ethanol distillation: the fundamentals," in The Alcohol Textbook, K. A. Jacques, T. P. Lyons, and D. R. Kelsall, Eds., pp. 319-336, Nottingham University Press, Nottingham, UK, 4th edition, 1995. 

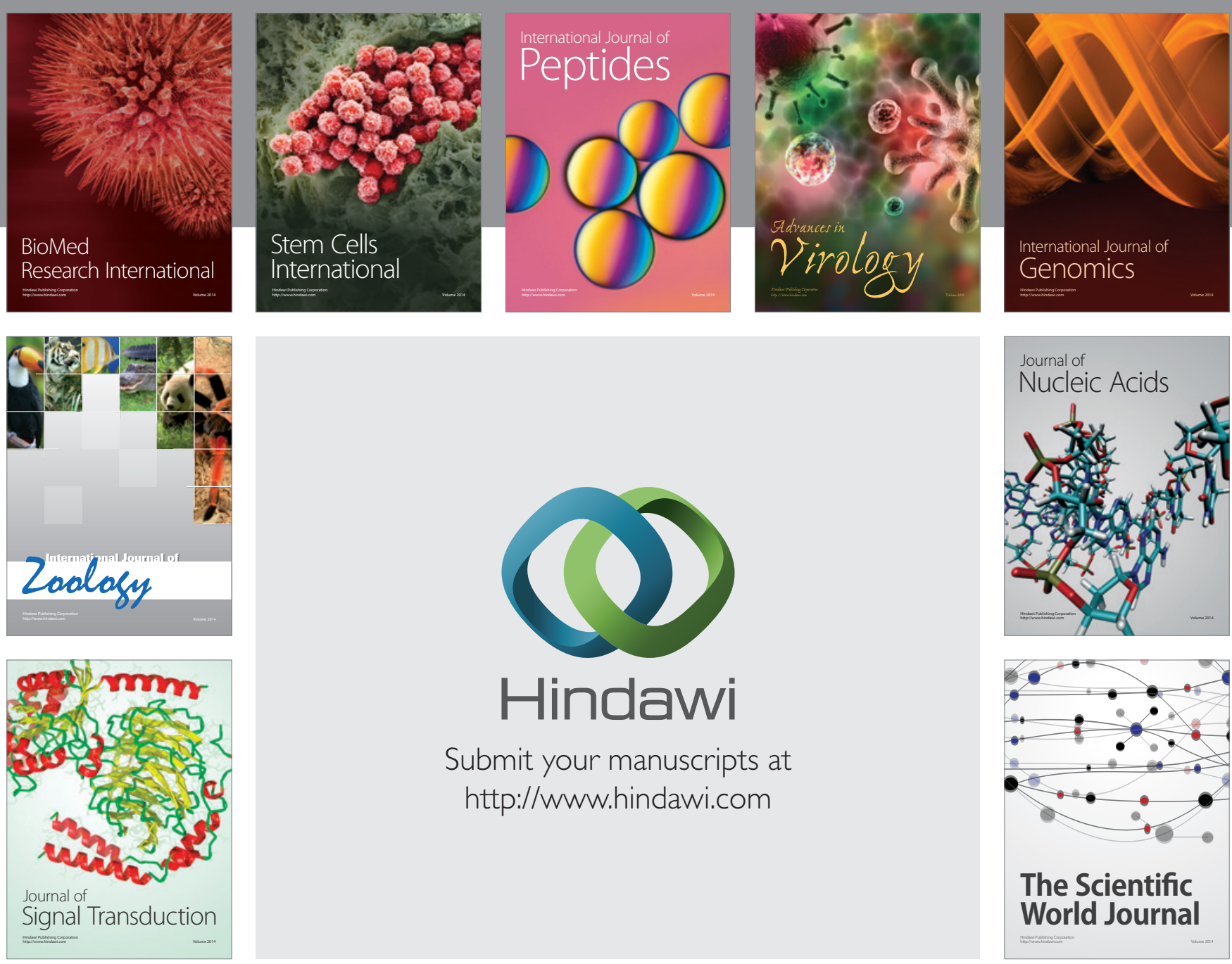

Submit your manuscripts at

http://www.hindawi.com
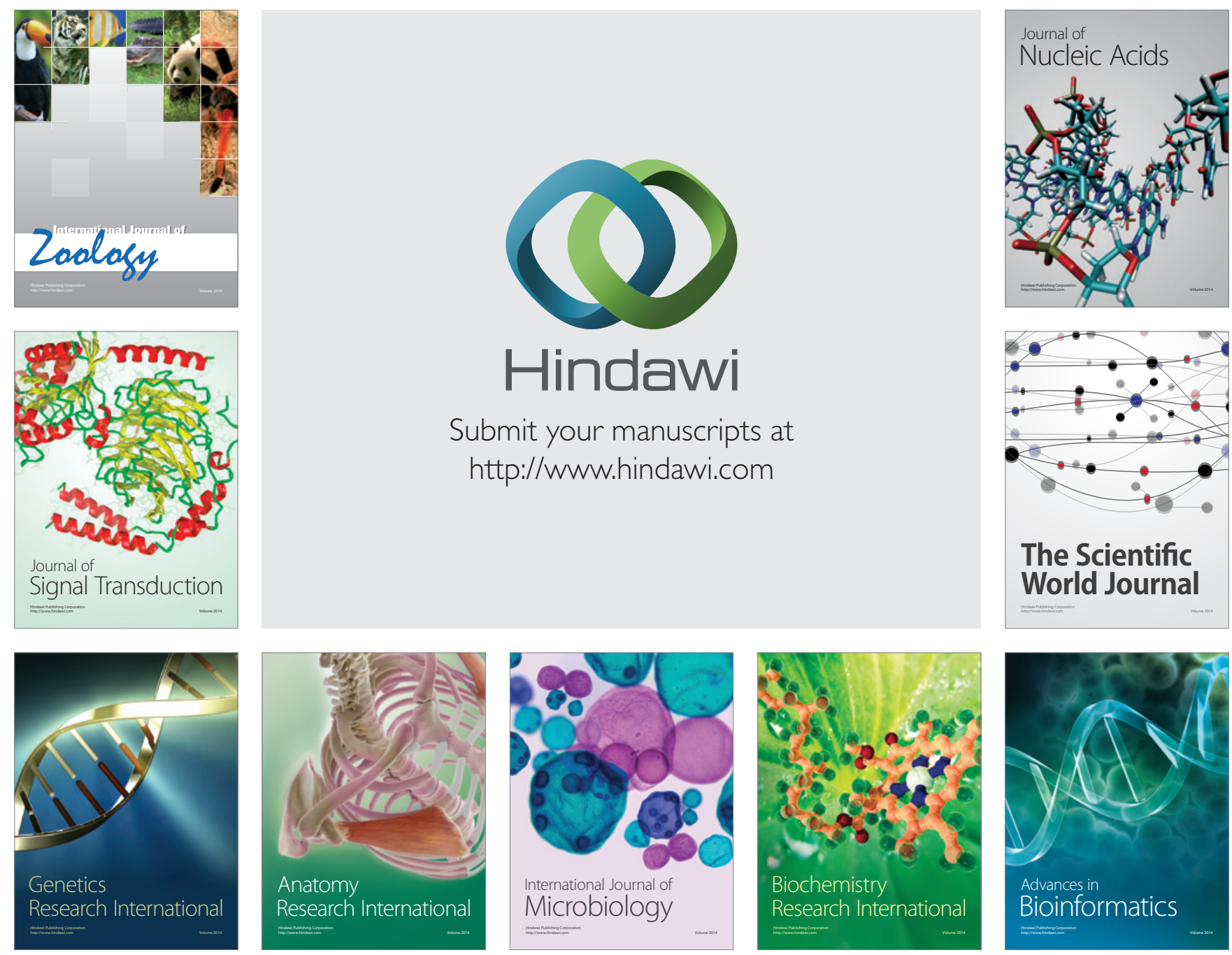

The Scientific World Journal
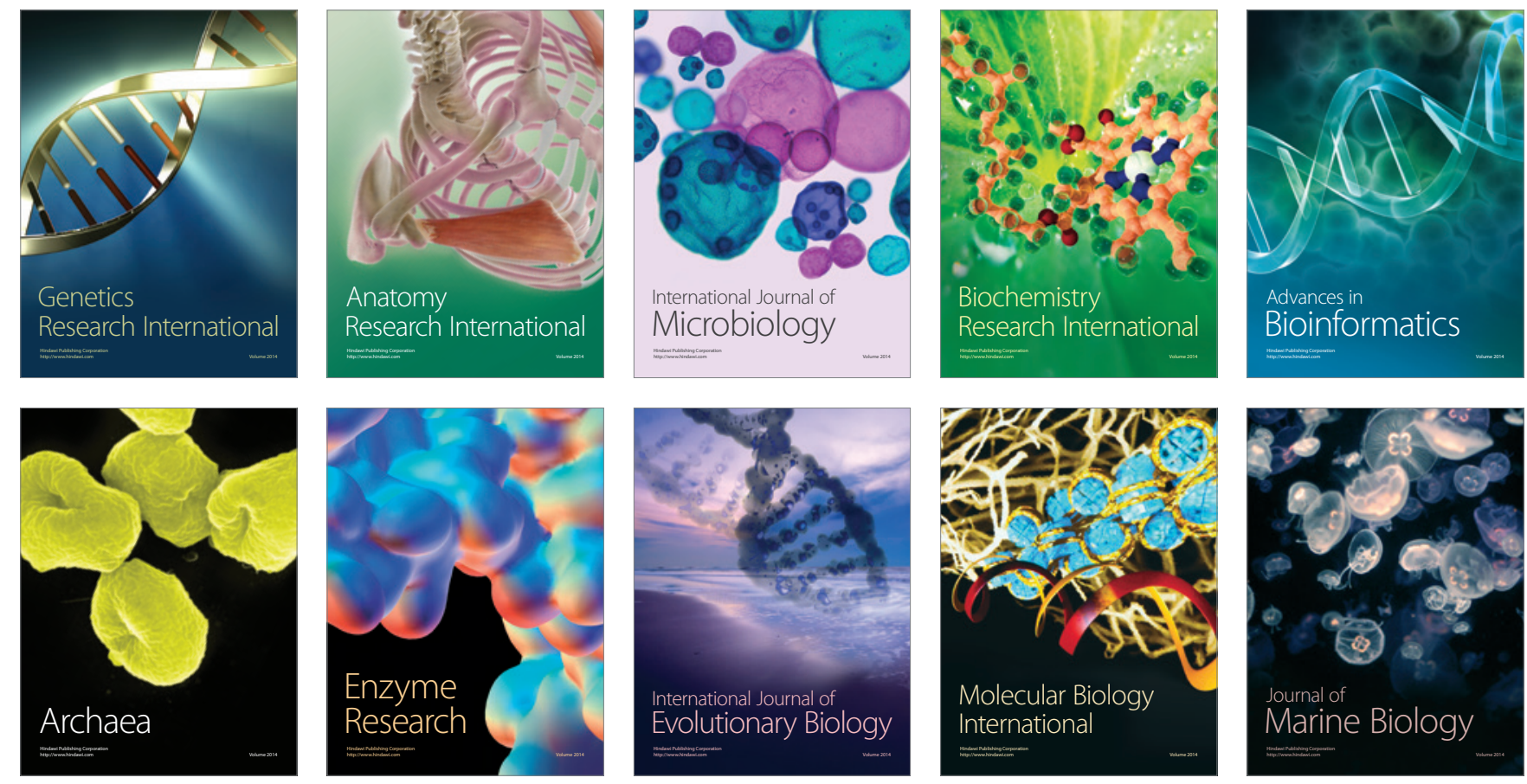